

\title{
EL OBISPADO DE PAMPLONA EN ÉPOCA VISIGODA
}

\author{
POR \\ JUAN JOSÉ LARREA \\ Universidad del País Vasco, Vitoria
}

\section{RESUMEN}

Este artículo quiere mostrar que la actitud del obispado de Pamplona con respecto a los concilios visigodos encuentra su explicación en el contexto del comportamiento general de fa Iglesia tarraconense, así como situar en sus justos términos un absentismo a menudo sobrevalorado por la historiograf́a. Además, frente a tesis que sostienen la idea de una sede precaria e inestable en una región total o parcialmente ajena al mundo hispano-visigodo, se revisan algunos lugares comunes, y, con ocasión del examen de los acontecimientos de 673 , se proponen algunas claves para la lectura de las fuentes tardoantiguas relativas a Vasconia.

\section{Abstract}

\section{The Bishopric of Pamplona in Visigothic times}

This paper means to prove that the attitude of the Bishopric of Pamplona towards the Visigothic councils can be explained within the context of the generat behaviour of the Tarraconense church; it also wants to situate the absenteeism of Pamplona, very often overvalued by the historiography, in its exact terms. Besides, against the theories that maintain the idea of a precarious and unsteady see in a region which was total or partiaily stranger to the Hispanovisigothic world, some common places are contested, and some guidelines are proposed for the interpretation of late Antiquity sources, on the occasion of the exam of 673 year's events. 


\section{PRESENTACIÓN}

Es bien sabido que las huellas del obispado de Pamplona en las fuentes escritas visigodas caben en unas pocas líneas: el obispo Liliolo suscribe las actas del III Concilio de Toledo y del II de Zaragoza (592). Casi un siglo más tarde, un diácono de nombre Vincomalo representa al obispo Atilano en el decimotercer concilio toledano (683) y al obispo Marciano en el decimosexto (693), último del que se ha conservado la nómina de asistentes. Un cuarto prelado pamplonés, Juan, aparece en el problemático decreto de Gundemaro'.

La conjunción de la irritante escasez de datos con el hecho de afectar ésta a un territorio y a una época importantes para algunas tesis mayores de la historiografía española relativa a la Antigüedad Tardía, es con seguridad la causante de la variedad de interpretaciones surgidas en torno a la mitra iruñesa ${ }^{2}$. Un somero repaso muestra desde una especie de obispado de campaña puesto y repuesto por las armas godas en territorio enemigo ${ }^{3}$ hasta una región de

\footnotetext{
' Para todas las referencias a las actas conciliares seguiremos la edición de J. Vives, Concilios visigóticos e hispano-romanos, Barcelona-Madrid 1963.

2 Desde el siglo XI aparece de modo esporádico en los textos el nombre vasco de Pamplona, Iruñea, sustituyendo al latino en expresiones referidas a la sede: e.g. Sancius. Yruniensis episcopus en A.J. Martín DuQUE, Doctmentación medieval de Leire (siglos IX a XI), Pamplona 1983, doc. $\mathrm{n}^{\circ}$ 39, ап̄o 1047.

${ }^{3}$ Esta es la lectura que sugieren A. BARBero y M. VIGL, Sobre los origenes sociales de la Reconquista: cántabros y vascones desde fines del Imperio Romano hasta la invasión mustilitana, en: Sobre los origenes sociales de la Reconquista, Barcelona 1974 [ ${ }^{1} 1965$ ], p. 79. Ha sido sostenida antes y después por otros. Lo hacen rotundamente A. CAMPIón (Obras completas HI. Navarra en su

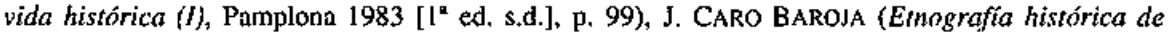
Navarra, Pamplona 1971-1972, t. I, pp. 81-83) o A.E. de MAÑARICÚA (Geografía eclesiástica del País Vasco peninsular (s. HI-XI), en: I Semana de Estudios de Historia Eclesiástica del País Vasco, Vitoria $198 \mathrm{~J}$, p. 232), para los cuales las fechas de asistencia a los concilios señalan los momentos de posesión visigoda de Pamplona. La idea está también, implícitamente, en A. BESGA (Consideraciones sobre la situación política de los pueblos del Norte de España durante la época visigoda del reino de Toledo, Bilbao 1983, pp. 47-48), quien piensa más bien en un absentismo debido a las incomodidades del viaje, pero aceptando en cualquier caso la relación entre obispado de Pamplona y posesión de la ciudad por los visigodos frente al enemigo vascón. En realidad, se encuentra desde antiguo en la historiografía la relación entre la escasa asistencia conciliar de la sede de Pamplona y la actividad militar en Vasconia (e.g. J. de MoreT, Investigaciones históricas de las Antigüedades del Reyno de Navarra, Pamplona I766, I, viii, 16), lo cual no es de extrañar dado el caŕcter casi monotemático de tas noticias referidas a los vascones en las fuentes. Nótese por otro lado que no es el único lugar en que se han relacionado ausencias conciliares con hipótesis de este tipo; así la asistencia a los sínodos visigóticos constituye un elemento fundamental del análisis de P. GOUBERT (Administration de iEspagne Byzantine: Revue des Études Byzantines, 4 (1946) 85-100) sobre los avances y retrocesos del dominio bizantino en la Península, si bien las conclusiones que resultan de ello están lejos de suscitar la unanimidad (cf. E.,A. THOMPSON, Los godos en España, Madrid 1971, \$12, л. 30).
}

De Hispania Visigoda

Hispania Sacia 48 (1996) 
asistencia conciliar constante ${ }^{4}$, desde un islote cristiano en un mar gentil ${ }^{5}$, hasta una diócesis que podría alcanzar la ría de Bilbao y cuyo absentismo no es sino prueba de buen criterio político y moral ${ }^{6}$. No falta quien, por prudencia, elude el problema ${ }^{7}$. Y también -dejemos constancia de ello- han sido enunciadas, aunque no argumentadas, ideas en la línea de las que vamos a sostener aquí ${ }^{8}$.

No se encontrará sin embargo el enfoque que tal vez debería haber sido el primero -y sospechamos que no lo ha sido por los apriorismos que obstaculizan toda aproximación a la Vasconia tardoantigua $-:$ ¿no parece cabal buscar

4 G. Balparda (Historia crítica de Vizeaya y de sus Futeros, t. I, Bilbao 1974 ['1924], p. 125) habla de una asistencia constante de los obispos de Vasconia a los concilios de Toledo, lo que justifjca considerando indistintamente a los de Calahorra y a los de Pamplona como representantes de una misma región. Todo esto sin perjuicio de considerar paganos los valjes pirenaicos (ibid. p. 134).

5 A. AzKARATE (Arqueología cristiana de la Antigüedad tardia en Alava, Guipuizcoa y Vizca$y a$, Vitoria 1988, pp. 517-519) pretendía y encontraba altamente significativo que las pocas apariciones de representantes de Pamplona en los concilios se dieran justamente en aquéllos en los que se mencionan cultos idolátricos; pero esta lectura de los datos no se basaba sino en un error, al confundir el decreto de Gundemaro con las actas del XII Concilio -de modo que situaba erróneamente a Juan, obispo de Pamplona, en éste- y al omitic toda alusión a la presencia del diácono Vincomalo en el decimotercero. En el provincial (Zaragoza 11) para nada se habla de idolatría. Recientemente, este mismo autor (Francos, aquitanns y vascones. Testimonios arqueológicos al Sur de los Pirineos: Archivo Español de Arqueología, 66, n' 167-169 (1993) 172) -manteniendo el error del decimosegundo concilio- parece retomar ta vieja tesis reseñada supra, nota 3. Por su parle, J.J. SAYAS (La búsqueda visigoda de la unidad serritorial y el caso vascónico: Veleia, 5 (1988) 205-206), que es víctima de la misma confusión que Azkarate con respecto al decreto de Gundemaro y el Xll Concilio, busca los motivos de la baja asistencia de Pamplona justamente en el hecho de tratarse de una comunidad cristiana rodeada por una población pagana y poco romanizada. No se entiende sin embargo la relación que Sayas plantea entre la sensación psicológica de cerco que él imagina en dicha comunidad y el absentismo episcopal.

${ }^{6} \mathrm{~J}$. GoN̄l (Historia de los obisposs de Pamplona. I. (s. IV-XII), Pamplona 1979) p. 53 sobre la inclusión de Vizcaya en la diócesis pamplonesa cntre los siglos IV y VI] -recogiendo la opintón de autores anteriores- y p, 47-48 sobre la postura de los prelados pamploneses ante los concilios.

${ }^{7}$ Es ésta la postura de J.M' LACARRA en diversas monografías, como La Cristianización del País Vasco, en: Vasconia medieval. Historia y fllología, San Sebastín, 1957, p. 54 o Novarra entre la Vasconia pirenaica y el Ebro en los siglos VII y IX, en: El hábitat en la Historia de Euskadi. Bilbao 1981, p. 160. Están recogidas en J.M LACARRA, Esrudios de Historia navarra, Pamplona 1982 e Investigaciones de Historia Navarra, Pamplona 1983, respectivamente.

${ }^{*}$ Es el caso de A.J. MARTín DUQUE en, por ejemplo, El señorío episcopal de Pamplona hasia I276, en: La catedral de Pamplona, Pamplona,1994, t. I, p. 73. Limítase sin embargo este autor a dejar constancia de su convencimiento personal.

9 Permitasenos un ejemplo. En un trabajo de J.J. SAYAS (La presión cristiana sobre los territorios vascónicos en época bajoimperial, en: Congreso de Estudios Históricos. Vizcaya en la Edad Media, Bilbao 1984, San Sebnstián, 1986, p. 61) pueden encontrarse las afirmaciones siguientes: 1) «Su [se refiere a Pamplona] escasa presencia cn los concilios -sólo en cinco contrasta con la relativamente asidua asistencia de algutnas de las sedes próximas. Huesca cstá representada en cinco concilios y es sede de otro, Zaragoza en catorce y fue sede de otros tres, Tarazona en cinco y Calahorta 
alguna clave, alguna orientación en el medio eclesiástico ${ }^{10}$ ? Puesto que hablamos de presencias y ausencias de una sede episcopal y partimos de las actas conciliares ¿no sería razonable comenzar por el contexto inmediato, por el análisis de la actitud de Pamplona a la luz de la dinámica general de su provincia, la Tarraconense?

De esta reflexión nace el presente trabajo. Se vertebra y hace reposar sus conclusiones en este análisis; pero no puede limitarse a la observación de la conducta de Pamplona desde la perspectiva de la Iglesia tarraconense si quiere ofrecer un discurso coherente capaz de responder a las objeciones mayores que pudiera suscitar. Así, en primer lugar, revisaremos un par de tópicos que acompañan con tenacidad a la mención de la sede pamplonesa en los trabajos históricos: aquél que hace equivalente ausencia del concilio y eclipse del obispado, y aquél que liga las apariciones de éste a las campañas militares desarrolladas en Vasconia. En segundo lugar, presentaremos el examen de los datos conciliares, tanto provinciales como generales, con el enfoque que acabamos de anunciar. Finalmente, la lógica del análisis anterior nos conducirá a repasar un acontecimiento clave del último período de la monarquía visigoda como es el levantamiento del duque Paulo, no sólo desde el punto de vista de los acontecimientos, sino, quizás sobre todo, desde el de las claves de lectura de las fuentes.

\section{OBISPADO, ASISTENCIAS CONCILIARES, CAMPAÑAS MILITARES}

Cuando se liga la aparición de la cátedra pamplonesa al sometimiento de vascones por el ejército, lo que se hace es basar un razonamiento muy discutible en una lectura impresionista de los datos. Es más que discutible asimilar

en nueve. [Los subrayados son nuestros]"s. Dejando de lado el hecho de que los datos son incorrectos, cuesta entender cómo habla Sayas de «relativamente asidua asistencia» para Tarazona y de «escasa presencia» para Pamplona, cuando cree que acuden al mismo número de sínodos, o como mucho, de acuerdo con su nota 54, que Tarazona asiste a seis. 2) Pamplona tendría una «estructura organizativa eclesial más retardada» porque, a diferencia de Zaragoza, Huesca y Calahorra, no manda abades como representantes, sino sólo a un diácono. Pues bien, siete de las quince sedes de la Tarraconense no han enviado jamás un abad a un concilio general, entre ellas la metropolitana. 3) Pamplona «no tenía claramente definido su territorio diocesano». Para justificar esto, no se nos dice sino que los límites de la Hitación de Wamba son poco fíables. Dejando de lado otras consideraciones sobre tan sorprendente secuencia lógica, ¿debemos pensar que Sevilla, Toledo o Mérida tampoco tenían claramente definido su territorio diocesano porque los límites que se les adjudican en la Hitación son tan poco fiables como los de Pamplona?

${ }^{10}$ Más allá, naturalmente, de la mela observación de que el absentismo episcopal era cosa corriente: J. GoÑi, op. cit., p. 48; L.J. ForTún y C. JusUE, Historia de Navara. I. Antigliedad y Alia Edad Media, Pamplona 1993, p. 54.

De Hispania Visigoda

Hispania Sacra 48 (1996) 
la ausencia de Pamplona en Toledo a la falta de titular del obispado -más aún a la inexistencia de éste. Y no es preciso alejarse mucho para encontrar ejemplos que muestran lo frágil de tal equivalencia. Así, nada sabríamos de los obispos calagurritanos antes de 589 si sólo tuviéramos las actas conciliares; ocurre que Calahorra, escenario del martirio de Emeterio y Celedonio, tiene la fortuna de ser cantada por Prudencio y de estar implicada en un conflicto recogido en el epistolario del Papa Hilario. Sin estas fuentes, no tendríamos constancia del rango episcopal de la ciudad ${ }^{11}$. Ebro abajo, recordemos que son la muerte del obispo León a manos de los bagaudas ${ }^{12}$ y las difíciles relaciones de San Millán con el obispo Dídimo ${ }^{13}$ quienes permiten que tengamos noticia de la existencia en la quinta y sexta centuria de una sede, la de Tarazona, que sin embargo no asiste a los concilios hasta 592. Se convendrá sin dificultad que se trata de fuentes y circunstancias excepcionales que no cabe razonablemente esperar en cualquier diócesis.

Más aún, si bien el grado de certeza no es total, Pamplona también proporciona una enseñanza en este sentido. Se desprende del decreto de Gundemaro conservado en la Hispana a continuación de las actas del XII Concilio de Toledo, junto con una constitución sinodal de contenido análogo fechada en 610. Como se sabe, este documento ha despertado sospechas desde hace tiempo. Hoy pueden encontrarse posturas diversas al respecto: J. Orlandis no ve mayor problema para otorgar la máxima fiabilidad al texto ${ }^{14} ; \mathrm{A}$. Barbero piensa que el fondo del decreto y de la constitución sinodal puede ser auténtico y corresponder efectivamente a una decisión tomada en el reinado de Gundema$\mathrm{ro}^{15}$; A. González sostiene que se trata de una falsificación urdida por el entorno real hacia $681^{16}$. Puestos en la peor de las hipótesis para la aceptación de la existencia real de Juan de Pamplona, debe señalarse que A. González llega a la conclusión de que los falsificadores debieron utilizar documentos auténti-

\footnotetext{
"Véase una síntesis en A. GonZÁLEZ, Los orígenes cristianos de la ciudad de Calahorra, en: Calahorra. Bimilenario de su fundación, Madrid 1984, pp. 231-245.

${ }^{12}$ Hydace, Chronique, A. Tranoy (ed.), París 1974, \$141.

13 Sancti Braulionis caesaraugustani episcopi Vira S. Emiliani, L. Vázquez de Parga (ed.), Madrid $1943, \$ 12-13$

14 J. ORLANDIS, La ambigua jurisdicción de la metrópoli toledana: Cuadernos de Historia de España, 63-64 (1980) 7-11, con observaciones sobre la cronología del decreto, que sería inmediatamente posterior a la constitución. Vid. también J. ORLANDIS y D. RAMOS-LISSON, Die Synoden auf der Iberischen Halbinsel bis zum Einbrich des Islam (7/I), Paderborn 1981, pp. 133-137.

is A. BARBERo, Las divisiones eclesiásticas y las relaciones entre la Iglesia y el Estado en la España de los siglos VI y VII, en: A. Barbero, La sociedad visigoda y su entorno histórico, Madrid I992 [']989], p. 193.

I6 A. GonZÁleZ, El decreto de Gundenaro y la historia del siglo VH, en: Los visigodos. Historia y civilización (Antigüedad y Cristianisnto : 3), Murcia 1986, pp. 159-169.
} 
cos de principios del siglo VII custodiados en los archivos de Toledo ${ }^{17}$. Se puede verificar que entre estos materiales auténticos se encontraba alguna nómina episcopal: dejando de lado otras provincias ${ }^{18}$, de los ocho obispos de la Tarraconense incluidos en el texto, seis son identificables sin problemas, sea en el concilio de Egara de 614 (Eusebio de Tarragona y Emila de Barcelona), sea en el II de Barcelona de 599 (Ilergio de Egara), o en ambos (Juan de Gerona, Máximo de Zaragoza y Munio de Calahorra). Quedan Floridio de Tarazona -pero Tarazona no asiste a ningún concilio entre 592 y $633-$ y el que nos interesa, Juan de Pamplona. Si no puede considerarse la existencia de éste como indiscutible, tampoco parece verosímil, si hubo falsificación, que los forjadores de ésta se la inventaran ¿Para qué, si se conformaron con hacer figurar unas cuantas sedes de cada provincia, y en ningún caso la totalidad? Mucho más probable parece que hubiera un Juan en la cátedra de Pamplona a principios del s. VII. Y nada sabríamos de él si no fuera por un documento, en el mejor de los casos de transmisión irregular, en el peor falso.

De lectura impresionista de los datos hemos calificado el intento de relacionar la mitra pamplonesa con la presencia de los reyes de Toledo al frente del ejército en tierras vasconas. En primer lugar, la relación entre las fechas de las campañas y las de las suscripciones de la sede pamplonesa es muy vaga. Hubo expediciones en 581 con Leovigildo, en algún momento del reinado de Recaredo posterior al fin de la crónica del Biclarense (590-601), en algún momento del reinado de Gundemaro (610-612), en 621 con Suintila y en 673 con Wamba; además de la de Rodrigo de 711, que dejamos a un lado por razones obvias. En suma:

$\begin{array}{lccccc}\text { CAMPANAas: } & 581 & 590-601 & 610-612 & 621 & 673 \\ \text { SuscripcIones: } & 589 & 592 & (610) & 683 & 693\end{array}$

Desde luego, como J. Goñi Gaztambide ha señalado", nada más inverosímil que hacer derivar la presencia del obispo católico de Pamplona en el III Concilio de Toledo de la campaña llevada a cabo en algún lugar de Vasconi ${ }^{20}$

\footnotetext{
${ }^{17}$ Ibid. p. 166.

${ }^{18}$ En las que también pueden identificarse fímantes del decreto. Așí, tres de los cuatro obispos de la Bética (Isidoro de Sevilla, Fulgencio de Écija y Pisino de Elvira) suscriben las actas del Concilio II de Sevilla (619). A. BESGA (op. cit., p. 47, n. 156) señala además con acierto que el cuarto, Agapio de Tucci, aparece citado en el Liber Iudictm, XII, ij, 13. Yerra en cambio (loc. cit.) al aducir los cosos de los obispos de Pnlencia y Sigüenza para justificar la autenticidad del decreto, pues no se encuentran en éste, sino en la constitución sinodal. Además, ignomamos en qué actas conciliares encuentra a Venerio de Cástulo fuera del documento en cuestión.

19 J. GoÑI, Loss obispos..., pp. 48-52.

${ }^{20}$ Recuérdese que, siendo Juan de Biclaro la única fuente al respecto, Victoriaco no ha sido satisfactoriamente identificado y que Leovigildo no ocupa toda Vasconia.
}

De Hispania Visigoda Hispania Sacra 48 (1996) 
por el mismo rey que establecerá obispos arrianos en el reino suevo conquistado. Una comunidad cristiana bajo-imperial en Pompaelo es perfectamente comprensible no sólo, como a menudo se ha señalado, por la proximidad de Calahorra y por la presencia de efectivos militares ${ }^{21}$, sino también porque está atestiguada la sensibilidad de al menos una parte de la población de la actual Navarra media a los nuevos cultos que se extienden por el Imperio desde su parte oriental ${ }^{22}$. Recientemente, las excavaciones llevadas a cabo en el subsuelo de la catedral han detectado, desde época romana, testimonios de carácter sagrado en el área donde se ubicará después la ecclesia, así como indicios de posibles enterramienos cristianos en los siglos $\mathrm{V} \mathrm{o} \mathrm{VI}^{23}$.

Sobre las acciones de Recaredo -en cualquier caso, en 590 como muy temprano- y de Gundemaro, ignoramos completamente cuándo y en qué parte de Vasconia se desarrollaron ${ }^{24}$. Y ciertamente, ningún representante pamplonés asiste a los concilios hasta más de medio siglo después de la incursión de Suintila. Por lo que hace a la campaña de Wamba, siete días de destrucción ...quaqua uersa per patentes campos depraedatio et hostilitas castrorum, domorumque incensio tam ualide acta est, $u t . .{ }^{25}$ - y marcha al galope para sofocar el centro de la rebelión comandada por Paulo, encajan mal con el restablecimiento de una sede episcopal. La cual, dicho sea de paso, no asiste al sínodo de 681 (Toledo XII). Por lo tanto, decir que las presencias conciliares de Pamplona están precedidas de expediciones militares no es falso. Pretender una relación directa entre ambas es un post hoc, ergo propter hoc particularmente generoso.

En el fondo, y esto es lo más importante, el paralelismo entre las dos series de datos resulta de la acumulación de fechas al principio y al final del período estudiado. Ahora bien, cuando existe un explicación distinta para la distribución cronológica de cada una de las dos series de datos, hay que pensar que

${ }^{21}$ A. Mañaricúa ha irsistido en estos dos hechos en diversas ocasiones. Así por ejemplo en $L a$ cristianización del País Vasco, en: Historia del Pueblo Vasco, San Sebastián 1978, pp. 64-66.

${ }_{22}$ Aś lo muestra el santuario mitraico encontrado en Arellano, en Tierra Estella, en la villa llamada «de las Musas»: Ma.A. MezQuíriz, La villa romana de "Las Musas" en Arellano: Trabajos de Arqueología Navarra, 10 (1991-92) 444; de la misma autora, La Arqueología Histórica en Época Romana en Navarra: Munibe, 42 (1990) 323.

${ }^{23}$ M*A. MEZquíRIZ IRUjo, Vestigios romanos en la Catedral y su entorno y E. ARAGONÉs, Época prerrontánica y románica, ambos en La catedral de Pamploma..., p. 131 y 135 respectivamente. Debe destacarse que el estudio de estos estratos está entorpecido por las destrucciones ilevadas a cabo para asentar las construcciones posteriores

${ }^{24}$ La Historia Gothorum de Isidoro de Sevilla no da precisiones en este sentido. Los pasajes relativos a las campañas de Recaredo y Gundemaro en C. Rodríguez (ed.), Las historias de los godos, vándalos y suevos de Isidoro de Sevilla. Estudio, edición crítica y traducción, León 1975, p. 264 y 270 .

${ }^{25}$ IUllanus ToletanUS, Historia Wambae regis, W. Levison (ed.), (MGH, SRM, V), \$ 50. 
nos encontramos ante una coincidencia casual. En el lado de las campañas militares conocidas, el vacío que se extiende desde la época de Suintila hasta 672 no es sino el reflejo lógico de la penuria de fuentes cronísticas o históricas en general entre la redacción de la Historia Gothorum isidoriana y la Historia Wambae regis de Julián de Toledo. El otro lado es el que vamos a someter a observación a continuación. Señalemos de todos modos que, en lo que respecta a los concilios generales, se trata de un período de 92 años en el que además de haber convocatorias solamente entre 633 y 656, la Tarraconense responde con bajas tasas de asistencia en general.

\section{CONCILIOS PROVINCIALES}

La Hispana nos ha transmitido las actas de diez concilios de carácter provincial. De ellos, cinco preceden al abandono del arrianismo por la monarquía goda. El más temprano, segundo de la colección tras el de Elvira, tuvo lugar en Zaragoza en 380. Dejando a un lado que no es posible identificar el origen de todos y cada uno de los doce obispos asistentes ${ }^{26}$, limitémonos a señalar que la fecha es demasiado temprana para sacar consecuencias sobre el particularismo de una región del mero hecho de no estar representada. Tras un intervalo de más de un siglo, los cuatro concilios siguientes - Tarragona (516), Gerona (517), Barcelona I (540) y Lérida (546) - sólo conciernen a la parte oriental de la Tarraconense. Se trata de reuniones a las que únicamente asisten los prelados de to que será Cataluña, más el de Zaragoza ${ }^{27}$. Huesca, Tarazona, Calahorra, Oca y Pamplona no toman parte en ellas ${ }^{28}$.

En lo que respecta a los concilios posteriores a 589, Liliolo de Pamplona estuvo en el II de Zaragoza (592), prolongación del III de Toledo en la tarea de extirpación del arrianismo, y fue -él o su sucesor- uno de los tres o cuatro que faltó al II de Barcelona (599). Más allá de esto, ignoramos si acudió a Huesca en 598, a Egara en 614 o a Zaragoza en 691: no es posible identificar la procedencia de los catorce asistentes de Egara y los otros dos carecen de nómina episcopal.

\footnotetext{
${ }^{26} \mathrm{Si}$ bien las hipotesis sobre el origen de los obispos cuyas sedes no han sido identificadas no apuntan desde luego a Pamplona: J. ORLANDIS y D. RAMOS-LISSON, Die Synoden..., p. 33.

${ }^{27}$ Además, Héctor suscribe como metropolitano de in Cartaginense el concilio de Tarragona y Oroncio de Elvira los de Tarragona y Gerona.

${ }_{28}$ No tienen pues mucho sentido preguntas como la de A. AzKARATE (Franco.s..., p. 172), quien se interroga por lo sucedido entre el primer concilio de Tarragona y 581 a la vista de la no suscripción de Pamplona en tas actas conciliares de ese perfodo. 
En suma, en el ámbito provincial, no hay modo de saber si Pamplona se comportó como un obispado absentista o si asistió a casi todos los sínodos en los que cabía esperar su presencia.

\section{CONCILIOS GENERALES}

Convendrá empezar por plantear el problema en sus justos términos. Hay representantes de Pamplona en los sínodos toledanos en 589 (III), 683 (XIII) y 693 (XVI); y desconocemos si también en 694 (XVII) -las actas no incorporan la lista de asistentes- y $i 703$ ? (XVIII) -sin actas conservadas. Ciertamente, se trata de la sede más absentista de su provincia. Pero si bien es cierto que transcurre casi un siglo entre su primera y segunda asistencia a los concilios generales -no tanto a Toledo, dado el testimonio del decreto de Gundemaro-, no lo es menos que todo el problema se reduce a un lapso de una veintena de años.

En efecto, no puede olvidarse que la distribución cronológica de los concilios generales, lejos de ser uniforme, se agrupa en dos tramos, precedidos por el muy especial sínodo de $589^{29}$. Encontramos en éste a Pamplona, tras lo cual discurren 44 años sin concilios generales hasta el IV (633), en que se instituye la regularidad de las asambleas. Se inaugura así la primera etapa, que comprende seis en 23 años y se cierra con Toledo X (656). Es en esta fase, y sólo en ésta, cuando falta la sede vascona. Después, 25 nuevos años sin concilios dan paso al segundo tramo, iniciado en 681 (XII) y acabado c. 703 (XVIII). En este período tienen lugar seis, de los cuales únicamente cuatro nos proporcionan la lista de asistentes, y de éstos, sólo tres cuentan con presencia de la Tarraconense: Toledo XIII (683), XV (688) y XVI (693). Pamplona asiste al primero y al tercero.

Dicho esto, intentemos aproximarnos a la comprensión de la conducta de la cátedra iruñesa desde el análisis de la provincia en que está integrada.

\section{La Tarraconense en los concilios de Toledo}

Los gráficos adjuntos muestran, desglosada por provincias ${ }^{30}$, la evolución de la asistencia a los concilios habidos en Toledo desde 589, con excepción

\footnotetext{
${ }^{2 y}$ Recuérdese por ejemplo, sobre la periodización de los concilios, el clásico trabajo de $\mathrm{R}$. d'ABADAL, Els concilis de Toledo, en: Homenaje a Johannes Vincke, Madrid 1962-63, pp. 21-45.

"ua Los gráficos se basan en la edición de las actas de J. Vives ya citada. De ahí algunas divergencias, mínimas, con respeclo a las tablas de C. SANCHEZ ALBORNOZ (Fuenes para el estudio de

De Hispania Visigoda Hispania Sacra 48 (1996)
} 
del noveno, el undécimo y el decimocuarto, por ser de carácter provincial, y del decimoséptimo y el decimoctavo por carecer, como acabamos de recordar, de nómina de asistentes y de actas, respectivamente.

En líneas generales, y tomando el conjunto de las sedes de Hispania y de Galia, se dibuja claramente una curva de asistencia más alta en los extremos cronológicos que en el tramo central. La respuesta a las convocatorias es masiva, superando el $80 \%$ de las sedes, en el mi Concilio (589) y el IV (633), así como en la última etapa, en los concilios celebrados bajo Ervigio y Egica ${ }^{31}$. Entre ambas, veinte años de sínodos habidos en época de Chíntila, Chindasvinto y Recesvinto conocen una asistencia situada más a menudo alrededor o por debajo de la mitad que en torno a las tres cuartas partes del total, proporción a la que unicamente se acercan los concilios VI (638) y VIII (653).

Puede apreciarse también -no descubrimos nada nuevo con ello- que el grado de éxito de cada convocatoria no resulta de la acumulación desordenada de voluntades individuales y círcunstancias particulares, sino que refleja una actitud clara del episcopado que se manifiesta en el marco de cada provincia. Prueba de ello es la similitud en las oscilaciones de las proporciones de ausentes de cada provincia a lo largo de la mayor parte de los concilios.

Ahora bien, ciertas provincias ponen de manifiesto un comportamiento particular. Por un lado, a través de la historia de los sínodos generales la Tarraconense es la provincia hispana más absentista, superada, eso sí, por la Narbonense, cuya curva de asistencia es más baja pero casi siempre paralela a

las divisiones eclesiásticas visigodas, en: Investigaciones y documentos sobre las instituciones hispanas, Santiago de Chiie 1970 ['1930], pp. 96-97). En relación a los gráficos V11-XIV de J. ORLANDIS y D. RAMOS-LISSON (op. cit, pp. 355-362) la diferencia es -aparte del desglose del JII Concilio- esencialmente de enfoque y de organización de los datos. Por claridad hemos obviado los problemas relativos a la provincia Carpetana segregada temporalmente de la Cartaginense, agrupando siempre en una columna los abispados que, sea desde el reinado de Gundemaro o desde el de Suintila, acaban dependiendo de hecho y de derecho del metropolitano de Toledo (sobre esta cuestión vid. A. BARBERo, Las divisiones eclesiásticas..., pp. 174-179 y 193-195). Obsérvense también las modificaciones en el número de sedes de la Bética (incorporación de Málaga entre los concilios tercero y cuarto) y de Lusitania y Galicia (restitución a Lusitania de Idanha, Lamego, Viseo y Coimbra antes de 666). En la Cartaginense, no se ha incluido el obispado de Cartagena a pesar de su aparición en el XI de Toledo, la erección de la sede de Baeza compensa en los gráficos la supresión de la de Cástulo y hemos optado por computar la sede de Denia desde el principio. Hemos preferido también pasar por alto lo relativo a algunas sedes de aparición raxa y problemática, como la Berecense de Toledo XIII o la de Elo que aparece en Toledo VII con el mismo obispo que Elche. Nada de esto afecta al anílisis que hacemos de los gráficos.

${ }^{31}$ Con la excepción del primero de la serie, Toledo XII $\{681\}$, a causa del abstencionismo masivo de la Tarraconense y la Narbonense.

De Hispania Visigoda

Hispania Sacra 48 (1996) 
la de su provincia limítrofe $\mathrm{e}^{32}$. Por otro, véase cómo los gráficos de la Bética, Galicia, Lusitania y la Cartaginense ${ }^{33}$ evolucionan de modo similar, mientras que en dos momentos la Tarraconense se aleja con una postura radicalmente distinta, a la vez que semejante a la Narbonense. Esto sucede en época de Chindasvinto, en el séptimo concilio (646), al que sólo acuden el metropolitano y el obispo de Ampurias frente a una asistencia más que regular de las otras provincias peninsulares y, con mucha mayor nitidez, en el reinado de Ervigio: en los concilios XII (681) y XIII (683), el contraste de la Tarraconense y de la Narbonense con el resto de las provincias es radical. En 681, frente a una asistencia aceptable de éstas, ni un solo representante de aquéllas, ni tan siquiera el metropolitano de la Tarraconense, suscribe las actas. Dos años después, la actitud es casi más insólita. La asistencia de representantes de la Tarraconense es total; de la Narbonense acuden siete de las ocho sedes, lo que no ocurría desde 633 y no volverá a suceder. Y sin embargo, no hay más que dos obispos de cada una de estas provincias en Toledo ${ }^{34}$. Los otros dieciocho, incluidos los dos metropolitanos, se hacen representar por delegados de rango inferior. Jamás se había visto nada semejante.

L.A. García Moreno ha interpretado la ausencia masiva de la Tarraconense y la Narbonense al séptimo concilio (646) como una manifestación de la oposición del Nordeste del reino a la política de Chindasvinto. Sería en cierto modo un síntoma de la animosidad que estallaría poco después con la rebelión de Froya ${ }^{35}$. De hecho, recuérdese que las decisiones de este concilio, y especialmente el primer canon, significativamente titulado De refugis atque perfidis clericis sive laicis, son una pieza más de la estrategia represiva del monarca y muestran la participación de elementos eclesiásticos en movimientos de oposición. Además de evocar disposiciones que limitan la eventual devolución de bienes confiscados, se constata y condena la colaboración de clérigos $a$ maximo gradu usque ad minimum en las conjuras destinadas a derrocar al anciano rey.

\footnotetext{
${ }^{32}$ Salvo en los dos últimos concilios incluidos en los gróficos. Pero téngase en cuenta que las actas del decimosexto concilio señalan una peste bubónica como causa de la ausencia de los obispos ultrapirenaicos: J. VIves, Concilins..., p. 515.

${ }^{33}$ Casi siempre esta última con niveles de asistencia más altos, lo que se comprende fácilmente dependiendo como depende del metropolitano de Toledo.

${ }^{34}$ En las actas hay una anomalía, señalada hace tiempo (E.A. THOMPSON, Los godos..., § 12, n. 27), referida a la representación de la sede de Oca: en las suscripciones, por un lado aparece Stercorius Aucensis episcopus y por otro Lohannes abba Areginei Aucensis episcopi [vicarius].

${ }^{35}$ L.A. GARCfa MORENO, Algunas cuestiomes de Historia navarra en la antigüedad tardía (siglos V-VIII), en: I Congreso General de Historia de Navarra, Pamplona 1987, t. 2, p. 414. Este autor (loc. cit.) también asocia la ausencia de cinco de los quince obispos tarraconenses en el VIII Concilio (653) con los disturbios en cuestión.
} 
Más espectacular es, como hemos dicho, el comportamiento solidario del episcopado tarraconense y narbonense en 681 y 683 . Hace tiempo que C.J. Bishko propuso buscar la explicación del anómalo incremento de delegados episcopales en 683 en las consecuencias de la rebelión de Paulo, si bien, estando limitada su observación a la presencia abacial en los concilios y al decimotercero de éstos, no dio la medida exacta de la radicalidad del fenómeno y emitió una hipótesis poco convincente en algunos de sus extremos ${ }^{36}$. Más tarde, R. d'Abadal apuntó la hipótesis de un episcopado nororiental completamente renovado por Wamba tras la revuelta, y por tanto fiel aún al rey recién depuesto por los promotores del duodécimo concilio ${ }^{37}$. Por su parte, J. Orlandis no duda en relacionar el sorprendente contraste entre la ausencia total del XII concilio y la asistencia masiva en el XIII con el interés que para el episcopado tarraconense y narbonense ofrecía la propuesta de amnistía para los rebeldes. Pero, en lo que se refiere al alto número de delegados, o bien no le concede ningún significado ${ }^{38}$, o bien - como $\mathrm{Abadal}^{39}$ - se limita a atribuirlo al interés puesto por el rey en promover la asistencia ${ }^{40}$, cosa que difícilmente explica la adscripción del fenómeno a sólo dos provincias -en las otras, los representantes no obispos se mantienen en las proporciones habituales.

Una visión general de la asistencia a los concilios como la que proporcionan los gráficos muestra que es la conjunción de las tres decisiones -absentismo total en 681, asistencia masiva en 683 y envío de un número absolutamente inusual de delegados de bajo rango- la que plasma el alejamiento solidario del obispado de estas provincias. Por supuesto, la explicación ha de buscarse, como han hecho Bishko, Abadal u Orlandis en el gran acontecimiento que había resquebrajado poco antes la cohesión entre estas regiones y el conjunto del reino. Es bien sabido que, tras el aplastamiento total de una revuelta

${ }^{36}$ C.J. BISHKo (Spanish abbots and the Visigothic councils of Toledo, en: C.J. Bishko, Spanish and Portuguese Monastic History. 600-1300, (Variorm Reprints: CS 188), Londres 1984 [11941], V, pp. 143-144) sólo se refiere a los ocho abades enviados por la Narbonense y la Tarraconense, sin bacer mención de los otros diez delegados de bajo rango. Piensa que la situación de estas partes del reino era aún demasiado inestable para que los obispos se permitieran dejar sus sedes, por lo que habrían recurtido al mando de delegados. Tal explicación no cuenta con lo sucedido dos años antes, cuando no se envío ni un solo representante a Toledo. En este sentido, compartimos las reticencias expresadas por E.A. THOMPSON (op. cit., p. 332 y n. 46) hacia la propuesta de Bisíko.

${ }^{37}$ R. d'ABaDAL, Els concilis..., p. 34. Nos parece más verosímil el alejamiento de la aristocracin provincial -y con ella de! episcopado- de la monarquía, que la destitución fulminante de ventitrés obispos por la corona. En cualquier caso, nótese que esta hipótesis no afectaría at objeto de estas páginas, es decir', a la participación de Pamplona en el comportamiento general de su provincia.

${ }^{38}$ J. ORLANDIS y D. Ramos-Lisson, Die Synoden..., pp. 265-266.

${ }^{34}$ Art. cit., p. 35 .

40 J. ORLANDIS, Abades y concilios en la Hispania visigótica, en: Los Visigodos. Historia y civilización..., p. 225.

De Hispanin Visigoda

Hispania Sacra 48 (1996) 
que contaba con un fuerte apoyo (quis tuorum pro fide recta occubuit? ${ }^{41}$ ), la represión -penas envilecedoras, pérdida de derechos, confiscación de patrimonios- se había abatido sobre un número considerable de laicos y de clérigos de diverso rango, afectando severamente a las aristocracias provinciales. Ocho años después, a tres meses escasos del destronamiento de Wamba, la actitud unánime de los obispos de la Tarraconense y de la Narbonense muestra que la herida sigue abierta y, al mismo tiempo, confirma la amplitud de los apoyos prestados a la rebelión. A los dos años, el decimotercero es el concilio de la amnistía para los represaliados -amnistía extensible a los condenados desde el tiempo de Chíntila (636-639). Es ahora cuando la presencia de ambas provincias es masiva, pero al tiempo fuertemente marcada por una delegación de bajo rango. Hecho éste que no pudo sino pesar en el ánimo de los asistentes, aunque sólo fuera en el orden simbólico por la posición subordinada a la que el ritual relegaba a los delegados carentes de rango episcopa ${ }^{42}$-en este caso a casi toda la Iglesia nororiental. En cualquier caso, este sínodo marca el inicio de su reincorporación. En los siguientes, las cosas vuelven a la normalidad.

\section{Pamplona en la Tarraconense}

La veintena de años en que Pamplona falta regularmente a los concilios generales corresponde a la etapa en que la asistencia de su provincia sólo supera en dos ocasiones la mitad de las sedes existentes y nunca pasa de los dos tercios. Por otro lado, obsérvese que los obispos iruñeses acuden a Toledo o se hacen representar cuando la asistencia de la Tarraconense es masiva o unánime $^{43}$. En otras palabras, Pamplona suele ir cuando toda su provincia va, y falta cuando su provincia se muestra reticente a las asambleas toledanas.

Vayamos ahora más allá de esta apreciación general, y fijémonos en su actitud en los dos momentos en que con más claridad el comportarniento del episcopado tarraconense plasma el juego de tensiones entre Toledo y una aristocracia provincial dispuesta a participar en las graves revueltas del tramo final del reino visigodo.

En lo que respecta al absentismo masivo de 646 , no cabe duda de que Pamplona puede participar del descontento general de las clases dirigentes de la provincia -máxime cuando la importante participación vascona en la ulte-

\footnotetext{
41 De la Insultatio vilis provinciae Gallia, en IUlanuS TOletanus, op. cit, p. 527.

${ }^{42}$ Cf. J. ORLANDIS, Iglesia, concilios y episcopado en la doctrina conciliar visigoda, en: J. Orlandis, La Iglesia en la España visigótica y medieval, Pamplona 1976 ['1965], pp. 175-176.

${ }^{43}$ N.B. : no es sólo Pamplona quien hace o deshace la unanimidad cuando acude o cuando falta. 
rior rebelión de Froya es bien conocida ${ }^{44}$-, pero nada puede afirmarse más allá de esto. En efecto, la sede que nos ocupa ni había acudido al cuarto concilio (633) al que asistieron trece obispados de los quince de su provincia, ni al quinto (636) al que fueron cuatro, ni al sexto (638) en el que estuvieron nueve. Una ausencia más no puede leerse igual que cuando se trata de obispados que acuden frecuentemente ${ }^{45}$.

En cambio, el que los obispos de la Tarraconense actúen de modo unánime en 681 y exterioricen dos años después sus diferencias activamente (envío de delegados de bajo rango) sí da pie a considerar que Pamplona participa de la política general de la Iglesia provincial. Así, ningún representante de esta sede asiste al concilio XII (681), un diácono firma las actas del XIII (683), y, en el contexto de vuelta a la presencia masiva de la Tarraconense en los últimos decenios del reino, se encuentra de nuevo en Toledo diez años más tarde, en el último concilio del que se conserva la nómina episcopal.

Cabe objetar que al fin y al cabo esta explicación del comportamiento del obispado pamplonés en la última fase de la historia de los concilios visigodos depende de un acontecimiento central, cual es la revuelta de Paulo, y de sus secuelas, y que no es obvio ni comúnmente aceptado que la región de Pamplona haya tenido relación directa con ella. Cierto, aunque el que la Iglesia de Pamplona no hubiera tenido activa con la revuelta -pudiendo reducirse todo a mera simpatía o solidaridad pasiva-, no afectaría al hecho de que con respecto a los concilios su comportamiento va en consonancia con el del resto de obispados tarraconenses. Pero es que además creemos que se puede postular que la Historia Wambae [HWR en adelante] no es en absoluto contradictoria con una hipotética implicación de los dirigentes de Pamplona en la rebelión.

\section{EL PROBLEMA DE LA RELACIÓN DE VASCONIA CON LA REBELIÓN DE PAULO}

\section{La lectura de los acontecimientos}

En realidad, el problema es viejo, de casi once siglos: ya en el período astur la lectura de los hechos da lugar a divergencias sustanciales en la hilazón de los acontecimientos. En las dos versiones de la Crónica de Alfonso III, se presenta la campaña de Wamba en Vasconia y la sublevación nobiliaria como

\footnotetext{
${ }^{44}$ Nuestra lectura de la carta de Tajón en Petiplement et société en Navarre de la fin du monde romain à l'âge féodal (IV'-XIY siècles), (en prensa).

${ }^{45}$ Creemos que en este mismo sentido debe valorarse la posibilidad sugerida por L.A. GARCía MORENo (Algunas cuestiones..., p. 415) en torno a la ausencia de Pamplona y Tarazona en el concilio reunido poco después de la revuelta de Froya. Cf. supra n. 35.

De Hispania Visigoda Hispania Sacra 48 (1996)
} 
dos hechos independientes entre sí, de tal modo que las noticias de esta última llegan a of́dos del rey cuando se encuentra inmerso en la primera. Así, en el texto rotense:

Astores et Uascones crebro reuelantes 'plures uices' edomuit et suo imperio subiugauit. Paulum quendam ducem prouincie Gallie directum statimque reuellauit et omnem patriam illam conturuauit. Acminibus Francorum adiubatus contra Bambanem regem ad prelium est preparatus. 'Quo predicto regi Uasconie per nuntium est delatum. Statim illis in partibus premouit exercitum. Paulum uero de ciuitate in ciuitatem fugientem persequitur rex... ${ }^{46}$

En la redacción «A Sebastián» toda relación, por circunstancial que sea, es eliminada. Los vascones no aparecen sino con los astures en la frase inicial del pasaje, común a las dos versiones y completamente desconectada del relato de la rebelión antitoledana ${ }^{47}$. Por su parte, la crónica de Albelda tampoco se caracteriza por respetar el orden de los acontecimientos transmitido por Julián de Toledo, pero sitúa, eso sí, la expedición contra los vascones como primer paso dado por rey tras tener noticia de la revuelta ${ }^{48}$.

La historiografía castellana bebió durante siglos en la redacción rotense ${ }^{49}$ si bien el conocimiento de $H W R$ dio lugar a curiosas combinaciones ${ }^{50}-$ y es esta versión la que sigue contando hoy con el favor largamente mayoritario de los historiadores ${ }^{51}$ : Wamba se encontraría así en una de las campañas casi

\footnotetext{
46 J. GIL, J.L. MORALEJO y J.I. RuIZ DE LA PEÑA, Crónicas asturianas, Oviedo 1985, p. 116.

${ }^{47}$ Astores et Uascones crebro rebellantes edomuit et suo imperio subiugauil. Galliarum prouincie ciues coniuratione facta a regno Gotorum se absciderunt regnoque Francorum se subdiderunt. Pro quibus restaurandis domandisque prouinciis Paulus dux Uuambane directus cum exercitu non solun iniunctum sibi negotium non peregit, sed contra parrian agens tyrannorum scelestium factus est princeps. (Ibid. pp. 115-117).

${ }^{48}$ Primo regni anno retullanten sibi Paulum ducem quum quadam parte Spanie seu cum omni prouintia Gallie, hic rex cun exercitatione Spanie prius feroces Vascones in finibus Cantabrie perdomuit, deinde pergens cunctis cibitatibus Gotie et Gallie captis ipsum postremo Paulum in Neumasense hurbe uictum... (lbid. p. 170).

49. J. Gll cita en ește sentido, además de fas crónicas najerense y silense, al tudense y al toledano (Ibid., p. 79). Por otro lado, recordemos también, en lo que se refiere a la historiografía de origen navarro, a J. de MORET (Investigaciones históricas.... I, viii, 14), que sigue la versión rotense.

${ }^{30}$ Así por ejemplo, R. JIMÉNEZ DE RADA (J. Fernández (ed.), Roderici Ximeni de Rada Historia de rebus Hispanie sive Historia Gothica, (Corpus Christianonum. Continuatio Mediaevalis: 72), Tumhout 1987 , \$II, iii y iv) conjuga el deseo de rapiña propio según él de los vascones -ut eius gentis etiam hodie facta et desideria atestantur, qui libenter rapiunt aliena, asegura (iii, 23-24)-, que les lleva a atacar diversos lugares en Cantabria y Pirineos forzando la respuesta de Wamba, con su alianza con el duque Paulo.

51 VÉanse por ejemplo las síntesis destinadas al público universitario de J. ORLANDIS, Historia del reino visigodo español, Madrid 1988, pp. 131-133; L.A. GARCía MORENo, Historia de Españo visigoda, Madrid 1989, p. 171; J.M MinguEZ, Las sociedades feudales, I. Antecedentes, formación y expansión (siglos VI al XHI), (Historia de España: 2), Madrid 1994, p. 46
} 
rutinarias emprendidas regularmente por los monarcas visigodos contra los vascones, cuando las malas noticias le sorprendieron y le obligaron a acabar rápidamente el trabajo para lanzar sus fuerzas contra los rebeldes.

Seguiremos sin embargo atentamente un consejo debido, valga la paradoja, a Alfonso III, quien recomendaba la lectura del relato de Julián ${ }^{52}$. El primer examen al que debe someterse el texto no es en absoluto novedoso. Varios autores se han interesado por el orden de los acontecimientos que se desprende de $H W R^{5.3}$. En un crescendo que comienza por narrar las primeras fechorías de los instigadores de la rebelión y acaba presentando la provincia devastada, la noticia de la conspiración nos es dada acto seguido de la unción de Wamba y presentada como prácticamente simultánea. Después, cuando las nuevas llegan al rey, éste toma la decisión de enviar a Paulo al mando de un ejército para sofocar el levantamiento. De nuevo, Julián aumenta poco a poco la tensión del relato; comienza por la traición inesperada de Paulo y de Rano* sindo, duque de la Tarraconense y acaba describiendo la catástrofe: Paulo se ha proclamado rey, toda la Narbonense y parte de la Tarraconense se han aIzado, multitudes de francos y de vascones colaboran con los rebeldes, Wamba corre incluso el riesgo de perder todo si se deciden a pasar a la Península. Es ahora y sólo ahora -illo tunc tempore, cum haec intra Gallias agerentur ${ }^{54}$-, en el punto culminante de la revuelta, tras toda una serie de acontecimientos, cuando encontramos al rey a las puertas de Vasconia. Es de la traición de Paulo y de la agravación de la situación de lo que tiene noticia, no de la rebelión en sí.

De la narración se desprende con claridad que cuando las primeras informaciones llegan a Toledo ${ }^{55}$, Wamba toma la decisión de mandar a Paulo a la Narbonense y de dirigirse él mismo a Vasconia ${ }^{56}$. Otra cosa es que el rey, ló-

\footnotetext{
52 .. beatum hilianum metropolitanm legito, qui istoriam huils temporis liquidissime contexuit (Ad Sebastianum, 1, en J. GiL et al, op. cit., p. 117).

S.3 Infra ת. 57.

${ }^{54} H W R 9$.

55 La suposición de E.A. THOMPSON (Les godos..., p. 251), no descartada por A. BESGA (op. cit., p. 46), en el sentido de que el ejército se dirigía contra los Vascones cuando el rey fue informado de la revuelta septimana no tiene fundamento en $H W R$, mucho menos el que las primeras noticias llegaran cuando la campaña vascona ya había comenzado, tal y como sostiene M. TORRES: Las invasiones y los reinos germánicos de España (años 409-7/I), en: Historia de España. III. España visigoda, R. Menéndez Pidal (dir.), Madrid 1976, p. 123.

sh En este sentido, estamos de acuerdo con A. AzKARATE, Algunas consideraciones sobre el siglo VII en el entorno circumpirenaico occidental, en: $t^{\circ}$ Congresso de Arqueologia Peninsular. Actas IV (=Actas dos Trabalhos de Antropologia e Emologia, t. 34, fasc. 3-4), Porto 1994, p. 320. Discrepamos sin embargo en que del texto de Julián se despienda la «participación conjunta por parte de vascones de ambos lados de los Pirineos» (ibid. p. 319). Azkarate parece seguir a M. Rouche en cuestiones fundamentales, pero la interpretación de RoucHe ( $L$ 'Aquitaine des Wisigoths aux Arabes

De Hispania Visigoda

Hispania Sacra 48 (1996)
} 
gicamente, no esperara la traición de sus duques y que la noticia de esto le sorprendiera en la ciudad de Cantabria. Ahora bien, si Vasconia no formaba parte de la rebelión, ¿por qué habría de distraer una parte del ejército del foco de la insurrección? ¿Acaso los vascones por sí mismos han hecho peligrar alguna vez la estabilidad del trono ${ }^{57}$ ? Creemos con A.J. Martín Duque ${ }^{58}$ que tiene fundamento ver en la acción de Wamba ${ }^{59}$-que a su vez no ignoraba los hechos de 653- el precedente de la última campaña visigoda en Vasconia: cuando tras la elección de Rodrigo la aristocracia tarraconense y septimana se alinea con la familia de Witiza y Agila se proclama rey, Rodrigo calca la decisión de Wamba y ataca el territorio vascón.

En realidad, el resumen de la campaña contenido en el Iudicium, posiblemente más cercano en el tiempo a los hechos que $H W R^{60}$, formula exactamente esta presentación de los acontecimientos, cuando se refiere a la reacción del rey y su entorno:

Huius rei nefariae temeritate compulsi sumus arma arripere, et tot interiacentibus terris, nefandorum perfidiam insectare. Unde ct ad horum coniuratorum tyrannidem proti-

(4I8-781). Naissance d'une région, París 1979, p. 102) es un tanto confusa, ya que parece situar a Wamba rechazando un ataque (?) de los vascones, antes de que éstos entren en relación con los rebeldes. En general, nuestra crítica a las tesis de Rouche sobre la Vasconia tardoantigua en Peuplentent et société...

${ }^{37}$ Discrepamos en este punto de la interpretación de A. BESGA (Consideraciones.... pp. 44-46) y de J. J. SAYAS (Euskal Herria y los pueblos germánicos, en: // Congreso Mundial Vasco. Congreso de Historia de Euskal Herria, Bilbao, 1987, S. Sebastián 1988, t. 1, p. 399). Ellos ya han ser̃alado el orden de acontecimientos que kemos descrito, pero piensan -sin lugar a dudas el primero, con menos claridad el segundo- en una operación contra los vascones prevista de antcmano y llevada a cabo pese al conocimiento de la rebelión en Septimania. Como Rouche (vid. supra), Besga cree en una agresión vascona previa.

${ }_{58}$ A.J. MARTÍN DUQUE, Tardoantigüedad, en: Gran Atlas de Navarra, Pamplona 1986, t. 2, p. 33. Por su parte, L.A. GARCía MoRENo (Alguna.s ctiestiones..., p. 415-416) también sitúa los acontecimientos de 672-673 como antecedente de la campaña de Rodrigo, a pesar de entender que Wamba se encontraba ya combatiendo a los vascones cuando se inició la revuelta.

${ }^{59}$ La acción preventiva fue según parece rípida, fácil y en un territorio rural no muy amplio: en HWR el contraste es bastante claro entre los escenarios urbanos de la costa mediterránea y los castra domusque que constituyen los únicos asentamientos citados en Vasconia (\$10). En cuanto a la poca extensión territorial, como ya observó J. de MORET (Investigaciones históricas..., 1, viii, 15), la imagen rural, los itinerarios -pese a las observaciones de E.A. THOMPSON (Los godos..., p. 250) sobre algunos errores geograficos de $H W R$ - y la corta duración de la campaña hacen pensar en una limitación de las operaciones al Sudoeste de Navarra. Pero -y esto no es más que una conjeturaquizás el ataque tuvo el efecto de impedir la coordinación que en 653 en cambio ya se había producido antes de la llegada de Recesvinto.

${ }^{60}$ Sería as de acuerdo con la cronología recientemente propuesta para ambos textos por $Y$. García (La cronología de la "Historia Wambae": Anuario de Estudios Medievales, 23 (1993) 121139). Para otros estudiosos del tema -e.g. W. Levison, en la introduccion a su edición de $H W R$, op. cit., p. 491- se trataría de obras salidas de la pluma de autores diferentes. 
nus extinguendam in Tarraconensem provinciam et in Gallias pugnantes accessimus et, đivina nobiscum comitante manu, ad ipsas usque civitates atque castella venientes, hos ipsos satellites defensoresque civitatum castrorumque feliciter cepimus ${ }^{6 \mathrm{t}}$.

Obviamente, es imposible in Tarraconensem provinciam accedere desde Vasconia, Cantabria, Calahorra o Huesca ${ }^{62}$.

No nos aferraremos sin embargo a este pasaje para escamotear otro problema: a nadie se le oculta que si recurrimos a examinar la secuencia de los acontecimientos para justificar la conexión de la Vasconia peninsular con la revuelta general del Nordeste del reino, es porque el modo en que presenta Julián lo relacionado con aquella tierra difiere del que utiliza para referirse a los demás escenarios y protagonistas del conflicto. Pero esto no resulta nada extraño en el conjunto de fuentes tardoantiguas relativas a los vascones.

\section{Historiografía y retórica}

En esencia, Julián hace dos cosas. Omite toda alusión a los motivos por los cuales Wamba se dirige con su ejército a Vasconia y oculta cualquier precisión sobre aquéllos que el rey subyuga bajo una imagen imprecisa, coloreada con el tópico de la ferocidad vascona. Es decir, simplificación del papel de los vascones y aplicación a éstos de un cliché literario: un doblete que es moneda corriente entre autores hispanos y francos. Recuérdese cómo el papel de los vascones en el asedio de Zaragoza de 653 en tanto que auxiliares de Froya en una revuelta nobiliaria se reduce en la Crónica Mozárabe -aún en el horizonte mental visigodo- al simple incursationem Uasconum non cum modico exercitus damno prospectat desprovisto de todo contexto, de tal modo que la usurpación frustrada desaparece de la historia ${ }^{63}$. O cómo al norte de los Pirineos, la revuelta del duque Lupo de 671-672 quedó reducida a Clotharius exercitum contra Wascones movit ${ }^{64}$. No es por otro lado una práctica exclusiva de los textos sobre vascones: a pesar de seguir a Hidacio, Isidoro -en una de las distorsiones características de su trabajo histórico ${ }^{65}$. elimina a los bagaudas y a su jefe Basilio del relato de los desastres de la Tarraconense en 449, para

\footnotetext{
${ }^{61}$ Iudicium in tyrannorum perfidia promulgatum, editado tras $H W R$, op. cit., p. 531.

${ }^{62}$ El que a continuación se diga primum ad Barcinonam cum exercitu accedentes (loc. cit.) no invalida nuestra observación, puesto que es efectivamente la primera ciudad tomada; además, el texto del Iudiciun omite por ejemplo la toma de Gerona que anota en cambio $H W R 11$.

${ }_{63}$ Chronica Muzarabica 2l, en I. GlL (ed.), Corpus Scriptortum Muzarabicortum, Madrid 1973, t. 1. A. Barbero y M. Vigll (Sobre los orígenes..., p. 65) han señalado esta distorsión sin sacar consecuencias de ella.

${ }^{64}$ M. ROUCHE, L'Aquitaine..., p. 100.

${ }^{65}$ C. Rodriguez (ed.), Las historias..., pp. 21 y $43-46$.

De Hispania Visigoda Hispania Sacra 48 (1996)
} 
sustituirlos nada menos que por godos, auxiliares a la sazón de la autoridad romana ${ }^{66}$.

Más tarde, en la crónica de Alfonso III, nadie se sorprenderá de encontrar viejas prácticas enraizadas en la tradición historiográfica visigoda. Ahondan en la simplificación del papel de los vascones que se apunta en $H W R$, reduciendo aquél a una frase tópica y asociando a éstos -viejo y bien conocido recurs $0^{67}-a$ otro pueblo marcado en los usos literarios por su indomabilidad, los astures ${ }^{68}$. Obsérvese también cómo la intervención de vascones ultrapirenaicos al mando del duque Lupo $^{69}$-cierto que tardía y poco honorable- se difumina en la $H W R$ al adjudicar a éste la nacionalidad franca, y cómo la presencia vascona entre los aliados que atrae Paulo, aunque atestiguada por Julián en $H W R 8$, desaparece completamente en las crónicas del período astur.

Cabe aún estudiar la presentación que Julián hace de los vascones desde otra perspectiva. Satis panegyrica para W. Levison ${ }^{70}$, el estrecho parentesco de esta obra de juventud ${ }^{71}$ con el género del panegírico ha sido subrayado por diversos autores ${ }^{72}$. Por supuesto, en tanto que escrito histórico, no se trata de que su estructura se amolde estrictamente a las pautas fijadas en la tradición retórica del basilikos $\log _{o s}{ }^{73}$. Ocurre más bien que, en una suerte de fusión en

\footnotetext{
${ }^{66}$ Ibid., p. 100. El texto completo de los pasajes en cuestión en HYDACE, Chronique..., § $140-$ 142 .

${ }^{67}$ Cf. infra n. 82. Recuérdese cómo Venancio Fortunato no vacila en evocar, junto con los vascones, a los legendarios cántabros como enemigos que temblarán ante el conde Galactorio de Burdeos (Ad Galactorium comirem, II, en F. Leo (ed.), Venanti Honori Clementiani Fortunati presbyteri italiciopera poetica, (MGH, $A A$, t. 4/1), Berlín 1881 , p. 251).

${ }^{68}$ No es en absoluto de extrañar el que la inclusión de los astures como pueblo dominado por Wamba carezca de toda justificación histórica. Hasta tal punto tienen fuerza estas tradiciones, que, de acuerdo con la lectura y la interpretación de J. Gil, los versos de exaltación de Alfonso III de la Crónica Albeldense -\$12-, salidos de mano gallega, incluyen nada menos que a los astures entre los enemigos vencidos. En el origen de tal paradoja, siempre según el citado autor, no se encuentra sino la usurpación de Fruela, pero upor inercia (...) se repite la antigua asociación de ideas, de suerte que la intriga palaciega es sustituida por las tópicas campañas contra ástures y váscones, los irreductibles pueblos cercados de ásperas montañas, que únicamente podtan ser emparejados en una brumosa lejanía.» (J. GiL et al., op. cit., pp. 94-95) ¿Buen ejemplo de la reducción de episodios complejos a simples clichés relativos a los pueblos septentrionales!

${ }^{69}$ M. ROUCHE, op. cil., p. 102.

${ }^{70}$ Op. cit., p. 491 .

7 Loc. cit. y J.N. HILLGARTH, Sancti Iuliani Toletanae sedis episcopi opera. Pars I, (Corpus christianorum. Series Latina: 115), Turnhout 1976, p. viii.

${ }^{72}$ Así por ejemplo, J.N. HILLGARTH (op. cit., p. xviii), M. TORRES (Las invasiones..., p. 123) o S. TElLLET (LHistoria Wambae est-elle une oeuvre de circonstance?, en: Los Visigodos. Historia y civilización..., pp, 415-424) ademas del ya mencionado W. Levison.

${ }^{73} \mathrm{Si}$ bien ciertos paralelismos son observables: vemos en el inicio el topico del consensus omnium (\$2) legitimador del derecho del rey a gobernar, adornado de una serie de detalles característicos de los panegíricos (M. TORRES, art. cit., p. 123, citando a F. Dahn). Se nos muestran después las 
absoluto desconocida en el mundo tardorromano ${ }^{74}$, el armazón narrativo sirve de soporte y se ve influído en su construcción por un contenido de orden panegírico ${ }^{75}$. Esto da lugar, en un texto non minus rethoris quam historici ${ }^{76}$, a un segundo nivel de lectura sostenido por el eco de Orosio, Virgilio, Salustio, Tito Livio, Isidoro... ${ }^{7}$

Desde este ángulo, el pasaje que nos interesa, y más precisamente la imagen que se nos da de los vascones y de su reacción ante la campaña real, se inserta en la larga tradición de la literatura retóriča. El eslabón clave está en nuestra opinión en el cultivador por excelencia del género en época germáni$\mathrm{ca}$, Venancio Fortunato ${ }^{78}$. En el conocido elogio dedicado a Chilperico con ocasión del concilio de Berny-Rivière en $580^{79}$, aquél no dispone de ninguna campaña militar contra enemigos externos digna de mención. Sin embargo, la defensa del pueblo contra éstos es uno de los tópicos fundamentales del basilikos logos, de modo que comienza resolviendo como sigue la servidumbre del género:

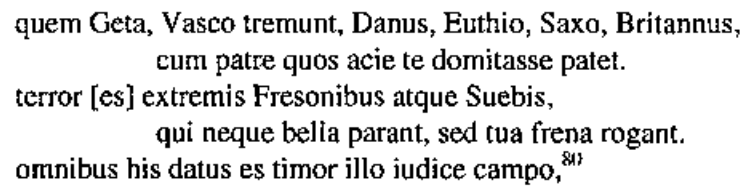

Asocia al rey al recuerdo de su padre, de historial más digno, y enumera una serie de pueblos. Algunos han podido efectivamente entrar en conflicto con Clotario ${ }^{81}$, si bien, de acuerdo con las reglas del género ${ }^{82}$, la verosimilitud no es en absoluto necesaria - «al estar obligados los oyentes a aceptar sin

virtudes de Wamba en la guerra, a lo largo de la mayor y más conocida parte del relato, tras to cual se hacen patentes sus cualidades en la paz; rey misericorde ( $\$ 25)$, rey piadoso que trae el respeto a la Iglesia, la prosperidad al pueblo y el orden al gobierno $(\$ 26,28)$.

${ }_{74}$ Cf. A. Cameron, Claudian. Poetry and Propaganda at the Court of Honorius, Ox ford 1970 , pp. 84 y $260-262$.

${ }^{75} \mathrm{~S}$. TElLLET, art. cit., en particular pp. 416-418, con indicación de algunos paralelismos en la tradición retórica.

${ }^{76}$ W. LEVISON, op. cit., p. 492.

${ }^{77}$ Vid. las notas de W. LEVISON en la edición citada. Por lo que se refiere a Isidoro, M.C. Dfaz y DiAz, Isidoro en la Edad Media hispana, en: M.C. Diaz y Díaz (ed.), Isidoriana, León 1961, p. 354.

${ }^{78}$ Autor que Julián conoce: J.N. HILLGARTH, op. cit., p. xvi.

79 J.W. GEORGE, Venantius Fortunatus. A Latin Poet in Merovingian Gaul, Oxford 1992, pp. 48 sq. (comentario) y $198 \mathrm{sq}$. (texto).

80. cit., 73-77.

8) A. BARBERO y M. Vigll. (Sobre los orígenes..., p. 52) piensan en la expedición franca de 541 para justificar la alusión a los vascones.

${ }^{2}$ Cf. A. CAMERoN, op. cit., pp. $96-97$ y 346.

De Hispania Visigoda

Hispania Sacra 48 (1996) 
pruebas los elogios» ${ }^{83}-$, y de hecho, otros tienen más que ver con el mundo de los poetas que con la realidad ${ }^{84}$. Acto seguido, acordando dimensiones casi épicas a acontecimientos bien modestos, menciona a suevos y frisones ${ }^{85}$, los cuales le dan pie para introducir un tópico que muy bien pudiera tener por objeto la evocación de uno de Ios emperadores «buenos», modelo clásico de gobernante $^{86}$. Nos referimos a Trajano, y más concretamente al panegírico de Plinio el Joven ${ }^{87}$, un modelo que Fortunato sin duda conoce ${ }^{88}$. Nótese que el tópico en cuestión no se aplica a los vascones, pero es introducido cerca de éstos y compartiendo lugar dentro de la estructura del poema.

Como se sabe, Isidoro -buen conocedor de los retóricos del Bajo Imperio $^{89}$ - está más interesado en construir un elogio del pueblo godo y en hacer encarnar en algunos reyes, sobre todo en Suintila, su ideal de príncipe cristiano, que en la precisión de la narración ${ }^{90}$. Su Historia Gothorum contiene en tres lugares mención de campañas dirigidas por reyes de Toledo en Vasconia. El tercero, en la llamada «redacción larga», se refiere a Suintila. Obsérvese la semejanza de la imagen con la que acabamos de destacar en Fortunato:

Habuit quoque et initio regni expeditionem contra incursus Vasconum Terraconensem prouinciam infestantium, ubi adeo montiuagi' ${ }^{91}$ populi terrore aduentus eius perculsi

\footnotetext{
${ }^{83}$ MENANDRO, Tratados, 371 (ed, y trad. F. Romero, Menandro: sobre los géneros epidicticos, Salamanca 1989).

${ }^{84}$ Este parece ser el caso de los euthiones, cuya patria es aparentemente Euthia, isla que Plinio el Vicjo situa ante las costas de Tesaiia: $N H, \mathrm{lv}, 72$.

${ }^{85}$ Con respecto a los suevos, Fortunato está evocando sin duda la embajada cnviada por Miro a Gontran de Borgoña que Chilperico hace detener en 580 . En general, creemos que deberían utilizarse con más tiento de to que a menudo se hace las informaciones «históricas» de Forlunato. No en vano panegyricum est licentiosum et lasciviosum genus dicendi in laudibus regum, in cuius conpositione homines multis mendaciis adulantur (ISIDORO, Etym. VI, viii),

Ro A. CAMERON, op. cit., p. 341.

${ }^{87}$ At nunc redit onnibus terror et neths ef uotum imperata faciendi. Vident enim Romanum ducem... (M. DURRY (ed. y trad.), Pline le Jetre. Tome IV. Lettres. Livre X. Panégyrique de Trajan, París 1964, § 12). Puede encontrarse una imagen similar en Claudiano: Bellum Geticum, 363-375, ed. J.B. HALL, Claudii Cloudiani Carmina, (Bibliotheca Teubneriana), Leipzig 1985.

${ }_{\mathrm{B} B}$ Cf. De Chariberctho rege, 82 (F. LEO (ed.), Venanti Honori, p. 133). Vid. J.W. GEORGE, Venantius Fortunatus..., p. 46, n. 52.

${ }^{89}$ C. RODRíguez, Las historias..., pp. 114-117. Sobre la postura de Isidoro de Sevilla ante la retórica, J. FONTAINE, Isidore de Séville el la culıure classique dan. I'Espagne wisigothique, París 1959, pp. 21 I sq. (en especial, p. 213-218).

Ibid., pp. 2j, 22, 37, 43-46, 50; 1. VAZQUEZ DE PARGA, Notas sobre la obra histórica de San Isidoro, p. 100, M. REYDELLET, «La conception du souverain chez Isidore de Séville», pp. 457-458 y 463, estos últimos en M.C. Díaz y Díaz (ed.), Isidoriana...

91 También se encuentra en Fortunato el adjetivo uagus aplicado a los vascones (supra n. 67). Es posible pues que esta asociación ađjetivo-etnónimo en la obra de ísidoro no provenga sólo de la errónea transmisión del virgiliano lateque furentes Barcaei (lateque vagantes Vaccei en Etyn. IX, ii,
} 
sunt, ut confestim quasi debita iura noscentes remissis telis et expeditis ad precem manibus supplices ei colla submitterent, obsides darent, Otogicus ciuitatem Gothorum stipendiis suis et laboribus conderent, pollicentes eius regno dicionique parere et quicquid imperaretur efficere ${ }^{92}$.

Julián de Toledo, en cuya $H W R$ se ha llegado a ver la «exaltación casi mística» ${ }^{93}$ de la realeza según el modelo isidoriano, se encuentra con un episodio que atañe a Vasconia en su construcción a dos niveles, histórico y panegíri$\mathrm{co}^{94}$. Confluyen así delante del escritor las necesidades de la narración con la posibilidad de engarzar una imagen ilustremente enraizada en la tradición literaria, siendo así que ésta le permite revestir al episodio de una función precisa en el panegírico real. Con maestría, el toledano, recordando el lugar común de la ferocidad vascona en lo que bien puede ser un eco de Tajón ${ }^{95}$, desarrolla un pasaje que es a nuestro parecer el reflejo de la imagen isidoriana, y en el fondo, otra variación del tópico de Fortunato ${ }^{36}$ :

Mox cum omni exercitu Vasconiae partes ingreditur, ubi per septem dies quaqua versa per patentes campos depraedatio et hostilitas castrorum domorumque incensio tam valide acta est, ut Vascones ipsi, animorum feritate deposita, datis obsidibus, vitam sibj dari pacemque largiri non tam precibus quam muneribus exoptarent. Unde, acceptis obsidibus tributisque solutis, pace composita, directum iter in Gallias..."

Julián domina los códigos y respeta las reglas del juego, Ahora bien, «cuando Eginhard, bajo el pretexto de pintarnos a Carlomagno, calca el retrato de Augusto por Suetonio, ya no hay, en sentido propio, testimonio que valgas ${ }^{98}$.

\footnotetext{
107) que ha mostrado R. CoLluNS, The Vaccaei, the Vaceti, and the rise of Vasconia: Studia Historica. Historia Antigua [=Homenaje al profesor Marcelo Vigil], 6(1988) 213.

92 C. RODRiGUEZ (ed.), op. cit., pp. 276-278.

${ }^{93}$ M. REYDELLET, art. cit., p. 466.

${ }^{94}$ S. TEILLET ( $L$ 'Historia Wambae..., p. 415) distingue tres: historia, panegírico y exempltm.

95 gens effera Vasconum (en la célebre carta a Quirico de Barcelona, $P L, t$. 80, p. 727-730). J.N. HiLlgarTH (Las fuentes de San Julián de Toledo: Anales Toledanos, 3 (1971) 99) juzga muy probable el conocimiento de la obra de Tajón por Julián. El eco del obispo zaragozano puede bien sospecharse a lo largo de $H W R$ en todo lo que rodea la oposición tirano / rey legítimo, tanto en el juego de adjetivos (e.g. \& 11, 26: princeps religiosus / Paulus pestifer; insanum caput) como en la caracterización de cada uno de los dos protagonistas y de sus actos. En el fondo, naturalmente, las obras de ambos autores están embebidas de la doctrina isidoriana de la realeza.

${ }_{97}$ Autor que tampoco es ajeno a las lecturas de Julián: J.N. HILLGARTH, art. cit., p. 102.

${ }^{97}$ HWR 10.

${ }_{98}$ M. BLOCH, Introducción a la Historia, Madrid ${ }^{(12)} 1992$, p. 93.
}

De Hispania Visigoda

Hispania Sacra 48 (1996) 


\section{CONCLUSIONES}

Ahora que los problemas que atañen a la Vasconia tardoantigua se ven sacudidos desde diversos campos por la aparición de nuevas luces y nuevos datos -de manera espectacular desde la arqueología ${ }^{99}$, pero también por parte de los historiadores de las sociedades septentrionales en la Antiguiedad ${ }^{100}$, conviene más que nunca dejar de arrastrar viejos -y cómodos- tópicos que no pueden sino entorpecer la integración de lo nuevo en el análisis histórico. Decir que conviene releer las fuentes puede parecer trivial. Sin embargo, en temas marcados por tradiciones historiográficas como la que nos ocupa, no es raro que abunden informaciones obtenidas con pocas precauciones. Creemos que el somero recorrido que hemos hecho por una serie de textos puede, al menos, ilustrar esta necesidad.

Por lo que respecta al objeto principal de este trabajo, las conclusiones son claras. La sede de Pamplona es la más absentista de la provincia más absentista de Hispania, pero ahí acaba toda su peculiaridad. Nada indica que su origen o sus presencias conciliares dependan de factores extraños a la generalidad de las diócesis, sean éstos de orden militar, político o religioso. Y no existen ni tan siquiera indicios mínimamente fundados de que el obispado se eclipse durante largos períodos.

El estudio de los datos en el contexto que les es propio muestra, en primer lugar, que únicamente en un período de 23 años -entre los reinados de Sisenando y Recesvinto, cuando la asistencia de la Tarraconense es generalmente baja- puede hablarse de ausencia sistemática. En segundo lugar, que la actitud de Pamplona responde a la dinámica del obispado provincial, lo que se pone especialmente de manifiesto en la última etapa conciliar, bajo Ervigio y Egica.

\footnotetext{
99 Así, entre las aportaciones tecientes de A. AZKARATE, Francos, aquiranos y vascones...

${ }_{100}$ Vid. los trabajos de $\mathrm{M}^{a} \mathrm{C}$. GonzÁlEZ, en particular Las unidades organizativas indigenas del área indoeuropea de Hispania, [=Veleia, anexo 2], Vitoria ]986, o los resultados del symposium Las estructuras sociales indigenas del Norte de la Península lbérica, $\mathrm{M}^{\mathrm{C}} \mathrm{C}$. González y J. Santos (ed.), (Revisiones de Historia Antigua: I), Vitoria 1994.
} 

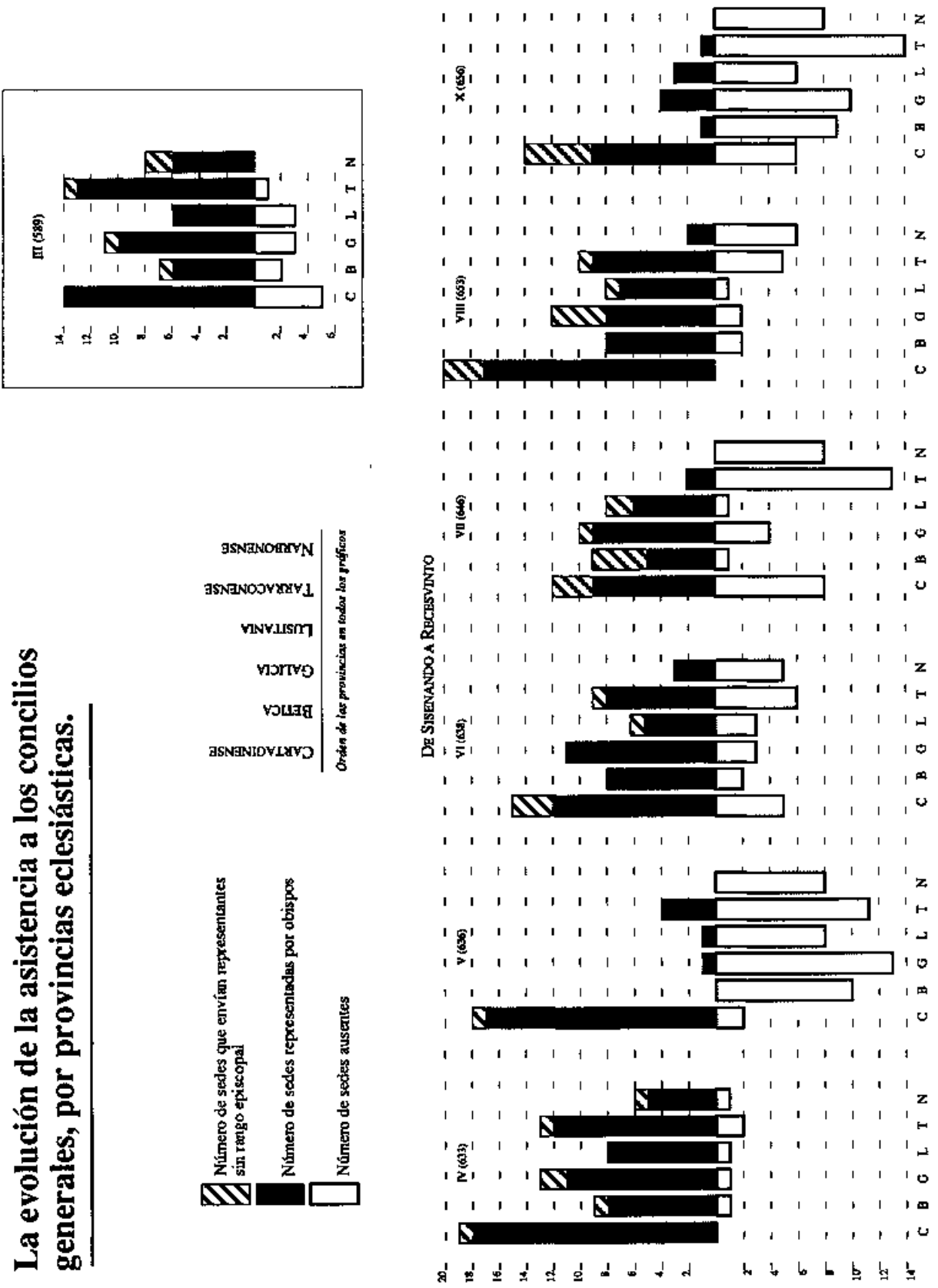

De Hisparia Visigada

Hispania Sacra 48 (1996) 


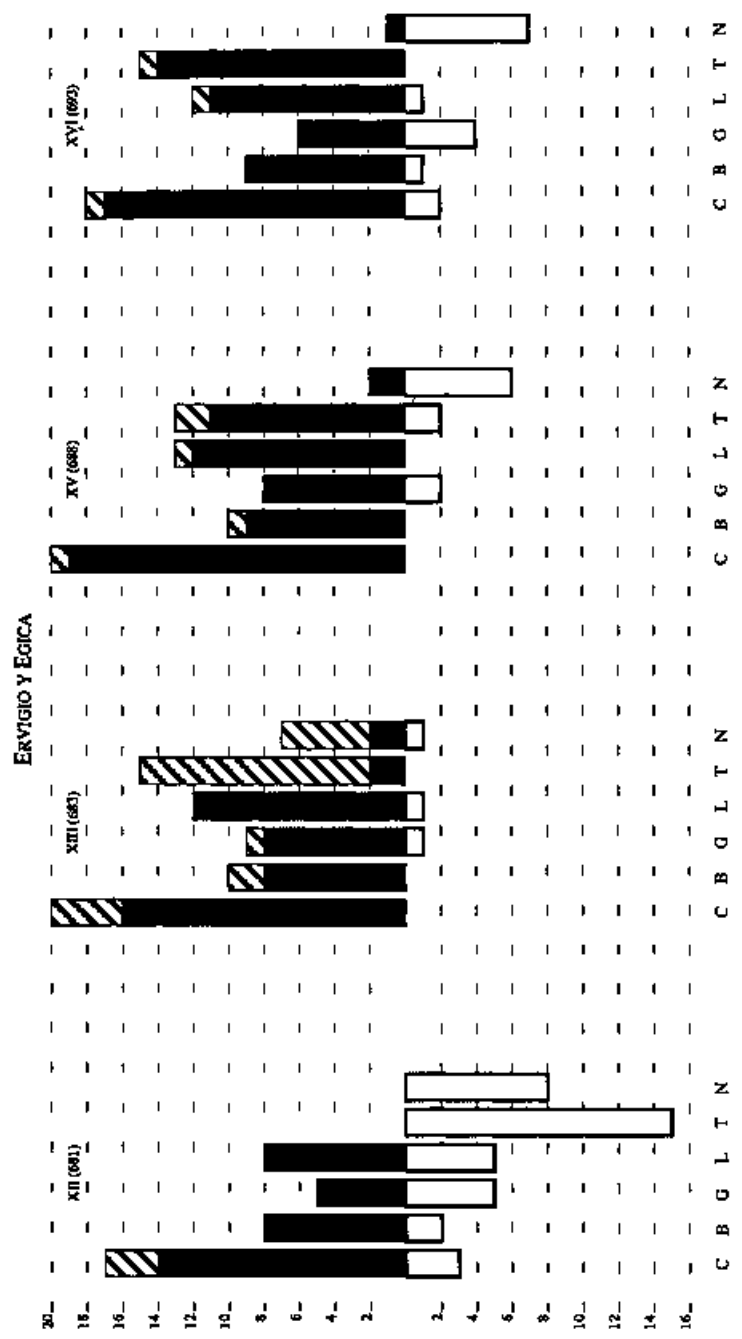

De Hispania Visigoda Hispania Sacro 48 (1996) 